\title{
Techniques in Quality Planting Material Production in Major Spices Crops
}

\author{
S.P. Khedkar*, V.B. Chavan and D. B. Chatase \\ Department of Horticulture, College of Agriculture, Dapoli, Dr. Balasaheb Sawant Konkan \\ Krishi Vidyapeeth, Dapoli-415 712, Ratnagiri (M.S), India
}

*Corresponding author

\begin{tabular}{|l|}
\hline Ke y w or d s \\
Quality, Material, \\
Spices, Techniques
\end{tabular}

A B S T R A C T

Spices like black pepper, cardamom, tree spices such nutmeg, cinnamon, clove are perennials and ginger and turmeric are grown annually. Most of them are propagated by vegetative methods. Non- availability of quality planting material is one of the important production constraints that affect the area expansion or gap filling programmes. Each crop requires specific techniques and handling to produces for planting material production from proven mother plants. The black pepper cuttings collected from mother plant are further multiplied by employing suitable rapid multiplication techniques. The simple and fast techniques are 'soil mound' with multiplication ratio of 1:40 in a year for production of normal cuttings. The micro propagated ginger can be raised using soil less medium in 18 or 20 well protrays, which is easy for transport and ensure pathogen free. In cardamom, vegetative techniques with average production of 32-42 suckers after 12 months of planting from one planting unite. Cardamom and turmeric are propagated through rhizome, around $1500 \mathrm{~kg} / \mathrm{ha}$ seed is required and this can be reduced by adopting novel single bud transplanting is popular with several advantages. In tree spices nutmeg and kokum propagated through softwood grafting and cinnamon by layering. Bush pepper and dwarf grafts are suitable urban horticulture and vertical farming. Use of growth regulators, ideal potting mixture and fortification with PGPR's or bio-control agents enhance seedlings vigour. By adopting these efficient multiplication techniques we can meet the quality planting material requirements of spices.

\section{Introduction}

India is the land of Spices. It is the largest producer, consumer and exporter of the spices in the World. According to the Spice Board of India, sixty three spices are grown in the country. Spices is growing up every year, But per capita land resources are decreasing day by day due to huge population pressure and industrialization. On the other hand casual natural hazards, pest and diseases outbreak etc. are also serious threats for getting that targeted outputs at a point of time. Sometimes problems like non-availability of quality and high yielding varieties. Low productivity mainly due to infestation of several diseases and pests, poor post-harvest handling practices, result in more production cost. Price insecurity and inadequate extension works are also major constraints against these 
rapid multiplication techniques. Hence, rapid multiplication of planting materials through modern propagation techniques is urgently needed. India is the world's largest producer, consumer and exporter of spices; the country produces about 75 of the 109 varieties listed by the International Organization for Standardization (ISO) and accounts for half of the global trading in spices.

The export of spices and spices products is growing up every year. But it is alarming that per capital and resources are decreasing day by day due to huge population pressure and industrialization. It is almost impossible to have a horizontal expansion of spice growing area. On the other hand casual natural hazards, pest and diseases outbreak, market fluctuation, etc. areal so serious threats for getting that targeted out puts at a point of time. But sometimes, they concerned with some problems like non-availability of quality and high yielding varieties, low productivity mainly due to infestation of several diseases and pests, poor post-harvest handling practices, result in more production cost. Even, price in security and inadequate extension works real so major constraints against these rapid multiplication techniques. Hence, rapid multiplication of planting materials through modern propagation techniques is urgently needed.

\section{Techniques in quality planting material production}

\section{Propagation techniques}

Conventional propagation needs a large quantity of planting material which results less sprouting ratio, more incidences of disease and pests and poor root development as well as field establishment. Modern propagation techniques are more advantageous over convention alone. Through modern propagation techniques production of virus free, disease and insect pest resistant planting material with large quantities within a shorter space of time can be possible. These plants grow faster and more vigorously. Also gives higher yield as compare to conventional methods.

\section{Turmeric}

\section{Single bud rhizomes method}

Planting of turmeric by traditional way required more amount of quality planting material but less availability and highest cost are the main constraint. Even though, it takes nearly five to six months for rhizome development along with better crop establishment. Hence, to overcome these constraints rapid multiplication of turmeric through single bud method is one of the best methods. For this, a disease free, one to one and half month old seed rhizomes, treated with car bendazim@2g/litre and monocrotophos are used.

These rhizomes are cut into small pieces having single bud, cured on palmmat, covered with $0.5 \%$ humic acid treated coco peat and sprinkled the water upto 4 days. These sprouted single bud rhizomes sown in portray contains coco peat (100g) and Pseudomonas fluorescens $(5 \mathrm{~g})$ and covered with polythene sheet. Finally after emergence of leaf, spray the crop with $0.5 \%$ humic acid and plant lets are ready for transplanting within 25-30 days.

Malhotra et al., (2016) reported that single bud techniques of turmeric for seedlings production in portray was more beneficial as compared to direct planting method as showed on Table 1.

Phan Van Tan (2016) Stepwise optimization of different plant is to change the growth regulator, reduce the level of macro-nutrition and add humate. The M2 medium (MS's 
macronutrition 1/4, MS's micronutrition + Morel's vitamin + coconut milk $10 \%$ + sucrose $25 \mathrm{~g} / \mathrm{l}+$ humate $1.0 \mathrm{ml} / \mathrm{l}+$ agar $7.5 \mathrm{~g} / \mathrm{l}$ $+2,4 \mathrm{D} 0.5 \mathrm{mg} / \mathrm{l}+\mathrm{BAP} 1.0 \mathrm{mg} / \mathrm{l}+\mathrm{TDZ} 1.0$ $\mathrm{mg} / \mathrm{l})$ is the highest ratio of callus induction. The TA3 medium (MS's macronutrition 1/4 + MS's micronutrition + Morel's vitamin+ coconut milk $10 \%+$ sucrose $25 \mathrm{~g} / 1+$ humate $2.0 \mathrm{ml} / \mathrm{l}+2,4 \mathrm{D} 0.5 \mathrm{mg} / \mathrm{l}+$ Kinetin $2.0 \mathrm{mg} / \mathrm{l}+$ TDZ $1.0 \mathrm{mg} / \mathrm{l}+\mathrm{BAP} 1.0 \mathrm{mg} / \mathrm{l} 2$ + NAA 2.0 $\mathrm{mg} / \mathrm{l}+$ activated carbon $2.0 \mathrm{~g} / \mathrm{l}$ ) is able to create buds and regeneration multiple bud for Curcuma sp. TA 3 medium adding IAA $2 \mathrm{mg} / \mathrm{l}$ and IBA $0.5 \mathrm{mg} / \mathrm{l}$ has resulted in the highest indices of quantity, healthy shoot and large diameter of roots. A large number of healthy plantlets are induced by the medium of MS's macronutrients $1 / 2$, MS's micronutrients full, Morel's vitamin, humate $3 \mathrm{~g} / \mathrm{l}$, coconut milk $150 \mathrm{ml} / 1$, activated carbon $3 \mathrm{~g} / \mathrm{l}$, composition phytohormone: IAA $2 \mathrm{mg} / \mathrm{l}+$ BAP $2 \mathrm{mg} / \mathrm{l}+$ TDZ $0.5 \mathrm{mg} / \mathrm{l}$.

\section{Ginger}

A transplanting technique in ginger by using single bud sprouts (about 5g) has been standardized to produce good quality planting material with reduced cost. The yield of ginger is at par with conventional planting system. The technique involves raising transplants from single sprout seed rhizomes in the portray and planting in the field after 30-40 days. The advantages of this technology are production of healthy planting materials and reduction in seed rhizome quantity and eventually reduced cost on seeds.

Sathyagowri et al., (2011) the conventional ginger propagation method is by rhizomes which have many limitations. Field grown ginger rhizomes with buds were rinsed thoroughly in running water then dipped in $70 \%$ ethanol for $1 \mathrm{~min}$. They were surface sterilized using Captan $0.3 \%$ followed by Doxycycline $0.2 \%$ for $10 \mathrm{~min}$ and finally with commercial bleach $20 \%$ of Cloro x TM. The sterilized rhizome buds of various sizes viz., $0.5 \mathrm{~cm}, 1.0 \mathrm{~cm}$ and $2.0 \mathrm{~cm}$ length were excised and cultured on MS medium with 3.0 mg L-1 BAP and $0.5 \mathrm{mg} \mathrm{L}-1$ NAA to select the suitable size of explants for the establishment of culture. Results revealed that explants of $0.5 \mathrm{~cm}$ length exhibited high rate of survival (66.67\%) and morphogenic response $(44.44 \%)$ among the explant sizes tested. Consequently the selected explants $(0.5 \mathrm{~cm}$ long) cultured were transferred to MS medium with $5.0 \mathrm{mg} \mathrm{L}-1 \mathrm{BAP}$ and $0.5 \mathrm{mg} \mathrm{L}-$ 1 NAA for shoot multiplication after 6 weeks of cultures. Thus micro-shoots were placed on the medium containing $3.0 \mathrm{mg} \mathrm{L}-1 \mathrm{BAP}$ and $0.5 \mathrm{mg}$ L-1 NAA to regenerate in vitro plantlets. The regenerated plantlets were successfully acclimatized. This might be helpful to obtain large number of in vitro planting material of ginger rapidly for cultivation.

Abbas et al., (2011) also developed the promising protocol for in vitro propagation of Zingiber officinale Rosco using sprouting buds was established. Sprouting buds were sterilized and cultured onto MS medium supplemented with different growth regulators. Augmentation of MS-medium with $4.5 \mathrm{mg} /$ litre BAP recorded the highest percentage of shoot lets multiplication. Shoot lets were highly rooted on half strength of B5 medium supplemented with $1.0 \mathrm{mg} /$ litre NAA. The maximum percentage of acclimatization, hardening and rhizomes production of in vitro derived plants in green house was $80-100 \%$.

\section{Rapid multiplication techniques of small cardamom}

Ankegowda et al., (2012) Small cardamom is propagated by rapid clonal propagation method. One grownup sucker and a young growing shoot are planted at $1.8 \times 0.6 \mathrm{~m}$ spacing, which is protected with erecting 
pandal. From one planting unit about 32-42 suckers produced after 12 months. Hence in one hectare of clone nursery about $1,48,144$ $1,94,439$ plants were produced in 12 months through rapid clonal multiplication techniques

\section{Micro propagation of cardamom}

Poudel et al., (2018) cultured in Murashige and Skoog (MS) medium enriched with 9 different concentrations of BAP (6benzylaminopurine) and IBA (indole-3butyric acid) namely $0.5 \mathrm{mg} / \mathrm{L}$ (BAP), 1.0 $\mathrm{mg} / \mathrm{L}$ (BAP), $1.5 \mathrm{mg} / \mathrm{L}$ (BAP), $2.0 \mathrm{mg} / \mathrm{L}$ (BAP), $1 \mathrm{mg} / \mathrm{L}$ (IBA), $0.5 \mathrm{mg} / \mathrm{L}$ (BAP)+ 1 $\mathrm{mg} / \mathrm{L}$ (IBA), $1.0 \mathrm{mg} / \mathrm{L}$ (BAP)+ $1 \mathrm{mg} / \mathrm{L}$ (IBA), $1.5 \mathrm{mg} / \mathrm{L}(\mathrm{BAP})+1 \mathrm{mg} / \mathrm{L}$ (IBA) and $2.0 \mathrm{mg} / \mathrm{L}$ $(\mathrm{BAP})+1 \mathrm{mg} / \mathrm{L}$ (IBA).

This study showed that the explants grown in MS medium supplemented with $1.0 \mathrm{mg} / \mathrm{L}$ $\mathrm{BAP}+1.0 \mathrm{mg} / \mathrm{L}$ IBA showed the maximum root induction rate. Buds produced roots in the same medium. The roots planted in the screen house were transplanted for the hardening process. Then these hardened plants were transferred to the netted nursery for further multiplication process. This protocol developed could be used for developing the superior quality plants of large cardamom.

\section{Cinnamon}

Waman et al., (2018) Air layering: Done on semi hardwood shoots $(25-30 \mathrm{~cm})$. Ring on bark shoot and a rooting hormone (IBA 2000 ppm or IAA $2000 \mathrm{ppm}$ ) is applied on the portion. Moist coir dust or coir husk is placed around and wrapping with a polythene sheet of $20 \mathrm{~cm}$ length. Rooting takes place in 40-60 days. Well rooted air layers are separated from the mother plant. Bagged in polythene bags filled with potting mixture. Rooted cuttings and layers can be planted in the main field with the onset of rains (Table 2).

\section{Black pepper}

Black pepper can be propagated by seeds, cuttings, layering, and grafting. Seed propagation of ten results in genetic variation while other methods of propagation are slow and time consuming.

So, there is a need to introduce efficient methods for rapid propagation of black pepper. In different countries of worlds like India, Sri Lanka black pepper is plants are multiplied rapidly in order to get more seedling in short duration and for quality planting material.

\section{Split bamboo methods}

A trench is made of $45 \mathrm{~cm}$ depth, $30 \mathrm{~cm}$ width and convenient length, filled with rooting medium comprising of forest soil, sand and farm yard manure in 1:1:1 ratio. Split halves of bamboo is fixed at 45 degree angle on a strong support. Rooted cuttings are planted in the trench at the rate of one cutting for each bamboo split. The lower portions of the bamboo splits are filled with rooting medium (preferably weathered coir dust-farm yard manure mixture in 1:1 ratio) and the growing vine is tied to the bamboo split in such a way so as to keep the nodes pressed to the rooting medium. As the cuttings grow, the bamboo splits are filled with rooting medium and each node is pressed down to the rooting medium and tied. When the vine reaches the top (3-4 months after planting of the cutting) the terminal bud is nipped off and the vine is crushed at about three nodes above the base, in order to activate the axillary buds.

After about 10 days, the vine is cut at the crushed point and removed from the rooting medium and cut between each node. Each cutting with the bunch of roots intact is planted in polythene bags filled with fumigated potting mixture. 
Table.1 Comparison of direct planting and transplanting (single bud rhizome) method of turmeric on sprouting and vegetative phases of the plant

\begin{tabular}{|c|c|c|}
\hline \multicolumn{1}{|c|}{ Growing Phase } & $\begin{array}{c}\text { Direct Planting method } \\
\text { (whole seed) }\end{array}$ & $\begin{array}{c}\text { Transplanting Method } \\
\text { (single bud rhizome) }\end{array}$ \\
\hline Sprouting phase. & 20DAP & $\begin{array}{c}\text { Plants have 34 leaves (1 month } \\
\text { old). }\end{array}$ \\
\hline Vegetative phase. & 2-3 leaves/plants & $6-7$ leaves per plants. \\
\hline One month after planting. & 3 MAP & 1 1/2-2 MAP \\
\hline Tillering stage. & Starts from 5 MAP & Starts from 3 MAP \\
\hline Rhizome development phase. & 7-9 MAP & 6-7 MAP \\
\hline Rhizome maturation phase. & & \\
\hline
\end{tabular}


The advantages of this method of propagation are rapid multiplication (1:40), well developed root system, higher field establishment and vigorous growth as a result of better root system.

\section{Serpentine method}

It is one of the cheapest propagation techniques for production of rooted cuttings of black pepper is serpentine layering. In a nursery shed with roofing sheet or shade net, rooted black pepper cuttings are planted in polythene bags containing about 500g potting mixture, which will serve as mother plants. As the plant grows and produces few nodes small polythene bags $(20 \times 10 \mathrm{~cm})$ filled with potting mixture maybe kept under each node.

The node maybe kept gently pressed into the mixture assuring contact with the potting mixture. Roots start growing from the nodes and the cuttings keep on growing further. Each node with the polythene bag is cut just below the rooted node. The rooted nodes will produce new sprouts in a week time and will be ready for field planting in two-three months' time. On an average, 60 cuttings can be harvested per mother plant in a year by this method.

\section{Soil mound method}

A soil mound of $2.5 \mathrm{mx} 0.60 \mathrm{~m}$ ( $45^{\circ}$ angle) of $2 \mathrm{~m}$ length (height) was prepared using locally available soil. In the upper layer of $5 \mathrm{~cm}$ of soil mound, well decomposed cow dung was mixed@1 kg/ $\mathrm{m}^{2}$. Rooted cuttings were planted at the base of soil mound in previously made trance at $20 \mathrm{~cm}$ spacing.

Khandekar et al., (2004) concluded that soil mound method of black pepper multiplication showed superior result over conventional method of multiplication and followed by split bamboo method and serpentine method of propagation respectively. The longest vine length, more number of node and branches per vine and number of roots per node also highest in soil mould method.

Similarly, the number of cuttings available per harvest, number of cuttings per year and maximum success percentage of cutting was greatest in soil mound method followed by split bamboo and serpentine method.

\section{Kokum}

Haldankar et al., (1992) Vegetatively propagated by softwood grafting. Use more than 22 weeks old seedling and 5-6 months old scion sticks are suitable. Sprouting in kokum softwood grafts was $82 \%$ and $76.5 \%$ in October and Feb - May months respectively (Table 3 ).

\section{Nutmeg}

Khandekar et al., (2006) the grafting method developed at Regional Coconut Research Station, Bhatye, Maharashtra provides scope for grafting nutmeg for prolonged period. May was the best month for soft wood grafting with maximum success of 80 per cent. There tension of leaves on rootstock did not influence the success of softwood grafting (Haldankar et al., 1999) (Table 4).

It is concluded that the literature reviewed here highlighted the Conventional propagation methods being slow, a rapid method of multiplication is needed especially for newly developed high yielding varieties, which are available in small quantities. Production of pathogen free healthy crop. Strengthened concept for quality production.

\section{References}

Abbas, M.S., Taha H.S, Aly U.I, Shabrawi H.M and Gaber S.I. 2011. In vitro 
propagation pf Ginger (Zingiber officinals Rosco). Journal of Genetic Engineering and Biotechnology 9(2): 165-172

Ankegowda, S.J., and Biju C.N. 2012. Propagation Techniques in Small cardamom. Spice facets. December 11, 2012.

Bhuyan, M.H.M.B., Rahman S.M.L and Sarker J.C. 2015. Explicating proper multiplication method for black pepper propagation in Bangladesh. Advance in Agriculture and Biology 4(2): 75-78.

Haldankar, P. M., Nagwekar, D.D. And Desai, A. G. 1997. Studies on Softwood Grafting in nutmeg. Indian J. Cooca Arecanut, Spices, 2-23.

Haldankar, P.M. 1992. Standardization of Softwood Grafting in Kokum $J$. Maharashtra agric. Univ., 17 (2): 227 229.

Khandekar, R.G., Haldankar P.M., Pande V. S., Joshi G.D., Bagade D.S., Malve D.B., Bhagwat N.R., Rangwala A.D., Jambhale N.D., Ramana K.V. 2004. Studies on rapid multiplication of black pepper (Piper nigrum L.) on soil mound. Journal of Spices and Aromatic Crops, 13 (1): 34-36.

Khandekar, R.G., Joshi GD, Daghoral, L.K., Manjrekar, R.G and Haldankar, P.M. 2006. Effect of time of softwood grafting on sprouting, survival and growth of nutmeg (Myristica fragrance Houtt.) grafts. Journal of Plantation Crops, 34 (3): 226-228.

Malhotra, S.K., Cherian $\mathrm{H}$ and R.Chitra, Balakrishnan S. 2016. Single bud rhizomes techniques of turmeric for seedlings production in portrays. Indian Journals of Arecanut, spice and medicinal plants 18(3):34-36.

Nasirujjaman, K., Uddin M.S, Zaman S, Reza M.A. 2005. Micro propagation of Turmeric (Curcuma longa L.) through in vitro Rhizome Bud Culture. Journal of Biology Sciences 5(4):490-492.

Phan, V. T. 2016. Micropropagation of Curcuma Sp., a Threatened Medicinal Plant. Advances in Bioscience and Biotechnology.7: 418-427.

Poudel, K., Prasai, H. R., Shreshta, J. 2018. Micropropagation and Acclimatization of Large Cardamom (Amomum subulatum Roxb.) Turkish Journal of Agriculture and Natural Sciences 5(3): 231-235.

Sathyagowri.S and Thayamini H. Seran. 2011. In vitro plant regeneration of ginger (Zingiber officinale Rosc.) with emphasis on initial culture establishment. Int. J. Med. Arom. Plants, Vol. 1, No. 3, pp. 195-202.

Waman, A.A and Bohra, P. 2018. Air layering in cinnamon (Cinnamomum verum $\mathrm{L}$.) under wet humid tropical conditions. Journal of Spices and Aromatic Crops Vol.27 (1): 71-73. 


\section{How to cite this article:}

Khedkar, S.P., V.B. Chavan and Chatase, D. B. 2019. Techniques in Quality Planting Material Production in Major Spices Crops. Int.J.Curr.Microbiol.App.Sci. 8(06): 1408-1415. doi: https://doi.org/10.20546/ijcmas.2019.806.170 